\title{
Pembuatan Sistem Informasi Rental Mobil dengan Menggunakan Java dan Mysql
}

\author{
Annisa Rahmawati, Rinta Kridalukmana, Ike Pertiwi Windasari \\ Program Studi Sistem Komputer Fakultas Teknik Universitas Diponegoro \\ Jalan Prof. Sudharto, Tembalang, Semarang, Indonesia \\ 544sha@gmail.com
}

\begin{abstract}
Abstrak - Pangsa pasar yang semakin berkembang di berbagai bidang usaha khususnya pada jasa, membuat sistem pembukuan penjualan yang belum menggunakan komputer menjadi tidak efektif. Salah satu contoh bidang usaha tersebut adalah usaha rental mobil. Proses pengolahan data transaksi perusahaan tersebut semakin tidak akurat dan lambat seiring dengan meningkatnya transaksi yang dilakukan. Atas dasar tersebut digunakan Sistem Informasi Rental Mobil yang berbasis komputer sehingga lebih cepat dan akurat. Sistem Informasi tersebut dibuat dengan menggunakan bahasa pemrograman Java dan menggunakan database MySQL yang tertanam langsung pada aplikasi. Proses pembuatan dan pengembangan Sistem Informasi Rental Mobil ini menggunakan metode SDLC (Software Development Life Cycle) model air terjun. Hasil dari perancangan aplikasi ini adalah suatu aplikasi desktop yang dapat memudahkan pengguna dalam pencarian mobil yang sedang tersedia, penagihan pembayaran dan pengembalian mobil jika batas waktu pengembalian sudah tiba.
\end{abstract}

Kata Kunci : Sistem Informasi, Aplikasi, Desktop, Java, MySQL

\section{PENDAHULUAN}

$\mathrm{P}$ ERKEMBANGAN teknologi semakin pesat pada masa kini.Kemajuan ini membuat Teknologi informasi menjadi kebutuhan yang tidak bisa dihiraukan lagi. (Gaol, 2008)Tuntutan bisnis yang menginginkan sesuatu secara lebih praktis dan akurat membuat suatu teknologi informasi menjadi hal yang tak terpisahkan dalam sebuah bisnis. Dengan adanya teknologi informasi, pengolahan informasi maupun data penting atau record menjadi lebih mudah dan dapat diandalkan.

Salah satu usaha rental mobil di Kabupaten Kudus yang bernama NT Rent Car mengalami kesulitan pada proses pengolahan data transaksi. Data transaksi yang masuk semakin banyak dan cenderung semakin tidak akurat juga lambat proses pengolahannya. Jika teknologi informasi dapat diimplementasikan dan usaha rental mobil ini memiliki sistem informasi untuk mendukung pengolahan transaksi tersebut, maka pasti usaha rental mobil ini akan mendapat kemudahan. Sistem Informasi Rental Mobil dapat menjadi pilihan untuk menjawab tuntutan kebutuhan tersebut.

\section{TINJAUAN PUSTAKA}

\section{A. Sistem Informasi Dalam Bisnis}

Sistem informasi adalah suatu alat untuk menyajikan informasi sedemikian rupa sehingga bermanfaat bagi penerimanya. Tujuannya adalah untuk menyajikan informasi guna pengambilan keputusan pada perencanaan, pemrakarsaan, pengorganisasian, pengendalian kegiatan. Suatu sistem mempunyai karakteristik atau sifat-sifat yang tertentu.(Al Fatta, 2007)

Berdasarkan sudut pandang bisnis, sistem informasi bukanlah hanya sekedar input, proses dan output semata. Sistem informasi sebagai pemecahan masalah manajemen dan organisasi berlandaskan pada teknologi informasi untuk menghadapi tantangan dari lingkungannya. Oleh karena itu untuk dapat merancang dan menggunakan isstem informasi, maka perlu memahami tentang organisasi, manajemen, dan teknologi. (Yakub, 2012)

\section{B. Pengembangan Perangkat Lunak Software Development Life Cycle}

Software Development Life Cycle (SDLC) merupakan sebuah siklus pengembangan perangkat lunak yang terdiri dari beberapa tahapan.Tahapantahapan tersebut adalah requirements (analisis kebutuhan), analysis (analisis sistem), design (perancangan), coding / implementation (implementasi), testing (pengujian), dan maintenance (perawatan). Dalam SDLC terdapat banyak metode yang dapat dipakai untuk mengembangkan sebuah perangkat lunak misal Waterfall, Spiral, Rapid Application Development (RAD), dan sebagainya. (Simarmata, 2007)

\section{Metode air terjun}

Metode air terjun adalah metode yang menyarankan sebuah pendekatan yang sistematis dan sekuensial melalui tahapan-tahapan yang ada pada SDLC untuk membangun sebuah perangkat lunak. Gambar 2.1 menjelaskan bahwa metode air terjun menekankan pada sebuah keterurutan dalam proses pengembangan perangkat lunak. Metode ini adalah sebuah metode yang tepat untuk membangun sebuah perangkat lunak yang tidak terlalu besar dan sumber daya manusia yang terlibat dalam jumlah yang terbatas. (Asmarul, 2000) 


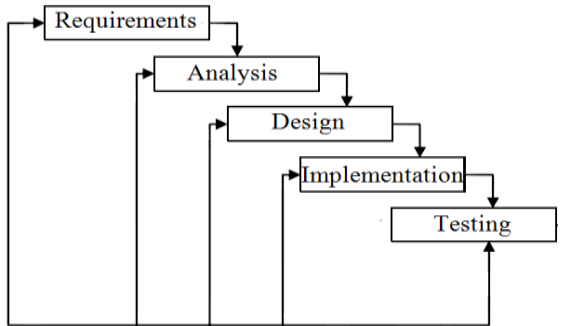

Gambar 2.1 Diagram WaterfallModel

\section{Flowchart}

Bagan alir (flowchart) merupakan bagan yang menggambarkan urutan dari instruksi proses maupun hubungan satu proses dengan proses yang lain dengan menggunakan simbol tertentu.

\section{E. Pemodelan Data Entity Relationship Diagram (ERD)}

ERD adalah sebuah model data yang menggunakan beberapa notasi untuk menggambarkan data dalam halentitas dan relasi yang digambarkan oleh data tersebut.

\section{F. Bahasa Pemrograman}

Saat ini terdapat banyak macam bahasa pemrograman untuk desktop, Java, Delphi, VB.Net, dan lain sebagainya.

\section{- Bahasa Pemrograman Java}

Java dikembangkan oleh Sun Microsystems pada Agustus 1991. Java disebut juga merupakan hasil perpaduan sifat dari sejumlah bahasa pemrograman, yaitu $\mathrm{C}$ dan $\mathrm{C}++$. Pemrograman Java bersifat tidak bergantung pada platform, yang artinya, java dapt dijalankan pada sembarang komputer dan bahkan pada sembarang sistem operasi. Sebagaimana halnya $\mathrm{C}++$, salah satu bahasa yang mengilhami Java, Java juga merupakan bahasa pemrograman berorientasi objek. Sebagai bahasa pemrograman berorientasi objek, Java menggunakan kelas untuk membentuk suatu objek.

Karakteristik Java antara lain adalah berorientasi objek (object-oriented), terdistribusi (distributed), sederhana (simple), aman (secure), interpreted, robust, multithreaded, dan dinamis.

\section{G. NetBeans}

Menurut Wahana Komputer (2012:15) NetBeans adalah sebuah IDE (Integrate Development Envirotment) open source yang sering disosialisasikan dengan Java. NetBeans merupakan salah satu proyek opensource yang disponsori oleh Sun Microsystem. Proyek ini berdiri pada tahun 2000 dan telah menghasilkan 2 produk, yaitu IDE dan NetBeans Platform.

\section{H. MySQL}

MySQL adalah sebuah perangkat lunak sistem manajemen basis data SQL(bahasa Inggris: database management system) atau DBMS yang multithread,multi-user, dengan sekitar 6 juta instalasi di seluruh dunia. MySQL tersedia sebagai perangkat lunak gratis di bawah lisensi GNU GeneralPublic License (GPL), tetapi mereka juga menjual dibawah lisensi komersial untuk kasus-kasus dimana penggunaannya tidak cocok dengan penggunaan GPL.(Solichin, 2011)

\section{PERANCANGAN SISTEM}

\section{A. Tahapan Pembuatan Sistem Informasi}

Untuk membuat sistem informasi yang baik harus melalui tahap perancangan sistem terlebih dahulu. Tahapan ini bertujuan untuk mengidentifikasi berbagai bidang permasalahan yang perlu segera dipecahkan maupun yang nantinya akan diselesaikan. Sistem informasi pada Tugas Akhir ini dirancang dengan menggunakan metode SDLC model air terjun. Model air terjun terdiri dari lima tahapan, yaitu: analisis kebutuhan, analisis sistem, perancangan, implementasi, dan pengujian.

\section{B. Analisis Kebutuhan}

Analisis kebutuhan harus dilakukan dengan baik (mendasar dan mendetail). Agar dapat lebih memahami sistem berjalan, selain diagram aktivitas perlu juga adanya use-case diagram. Use-case diagram ini menunjukkan fungsionalitas suatu sistem dan bagaimana sistem berinteraksi. Use-case diagram menunjukkan sejumlah actor, use-case, dan hubungannya dalam sebuah sistem. Di dalam sistem ini terdapat 2 aktor, yaitu admin (karyawan NT Rent Car) dan penyewa.

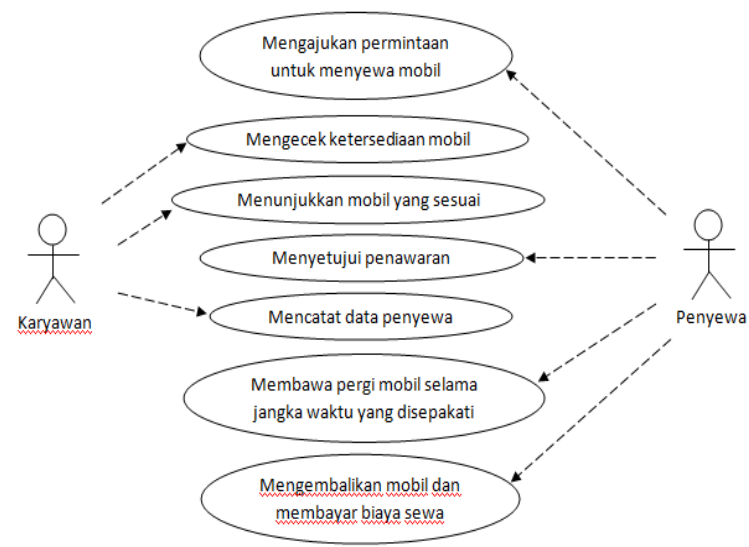

Gambar 3.1 Use-Case Diagram Sistem Berjalan 
Selanjutnya pada gambar 3.2 berikut ini ditampilkan diagram aktivitas sistem berjalan.

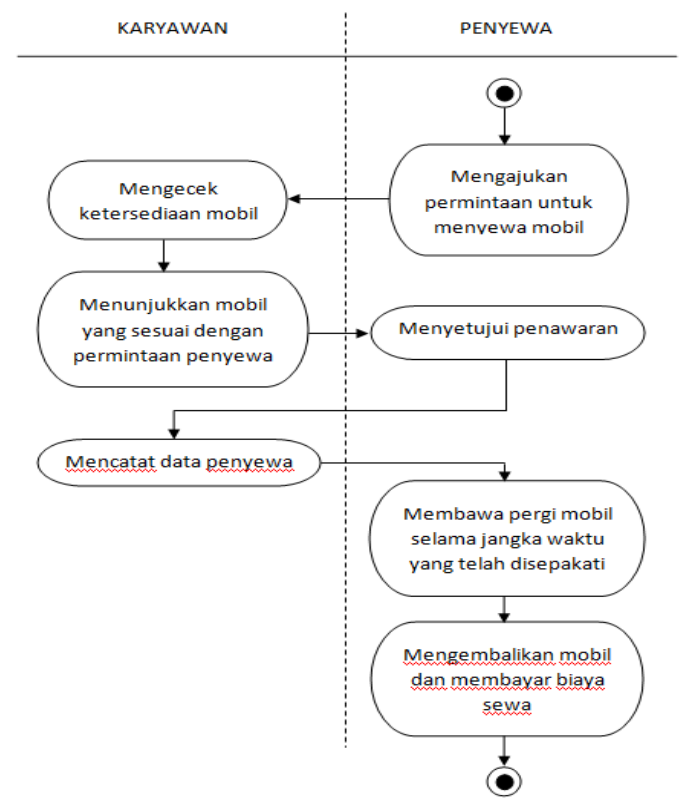

Gambar 3.2 Diagram Aktivitas Sistem Berjalan

C. Perancangan Sistem

1. Kebutuhan Fungsional

Kebutuhan fungsional meliputi fungsi-fungsi yang harus dapat dilakukan oleh sistem, yaitu:

1. Halaman Login.

2. Halaman Add Mobil.

3. Halaman Pinjam Mobil,

4. Halaman Pengembalian Mobil

5. Halaman Add User

6. Halaman About

2. Kebutuhan Nonfungsional

Rumusan kebutuhan nonfungsional untuk sistem informasi rental mobil meliputi:

1. Aplikasi harus mampu melakukan verifikasi saat pengguna ingin masuk ke sistem.

2. Hanya karyawan yang sudah terdata di basis data yang dapat masuk ke dalam sistem.

3. Menggunakan enkripsi password MD5.

3. Rancangan Sistem Usulan Berdasarkan Pemodelan UML

Secara umum prosedur yang akan dilakukan oleh admin dengan sistem informasi usulan ini yaitu setiap karyawan yang ingin mengakses informasi dalam sistem informasi rental mobil haruslogin sebagai admin.Setelah melakukan login maka admin dapat melakukan penambahan, penghapusan, maupun perubahan data. Perancangan sistem informasi usulan menggunakan diagram UML. a. Use-Case Diagram Sistem Informasi Rental Mobil

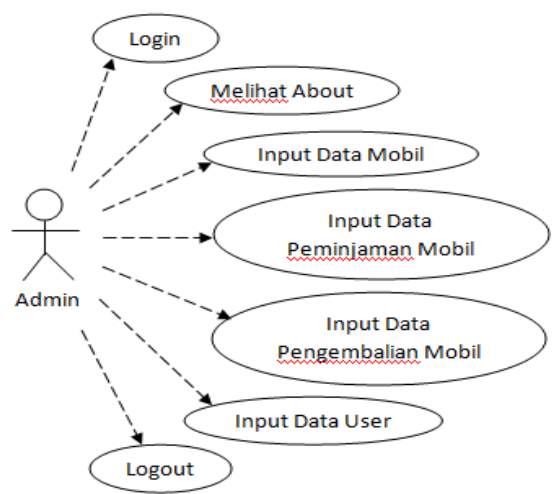

Gambar 3.3 Diagram Use-Case Sistem Informasi Rental Mobil

b. Diagram Aktivitas Sistem Informasi Rental Mobil Prosedur sistem usulan dapat dilihat pada diagram aktivitas pada gambar berikut.

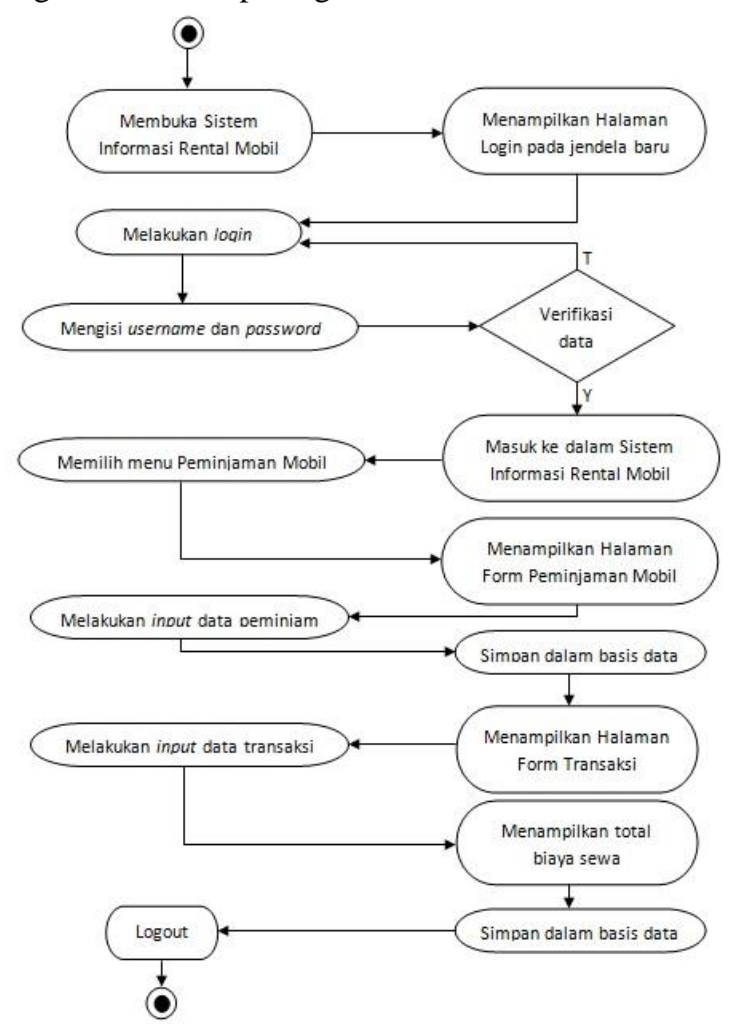

Gambar 3.4 Diagram Aktivitas Peminjaman Mobil yang Diusulkan 


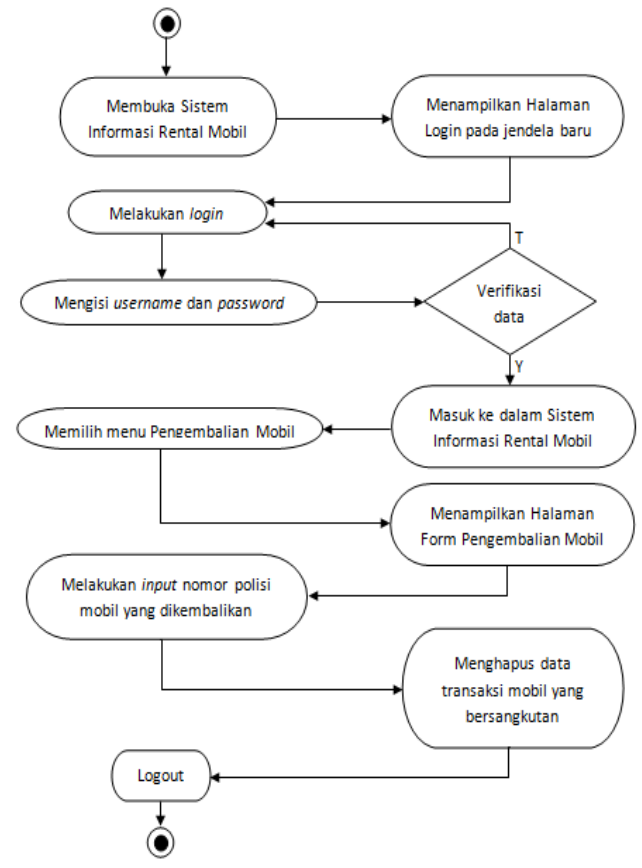

Gambar 3.5 Diagram Aktivitas Pengembalian Mobil yang Diusulkan

\section{c. Diagram Kelas}

Diagram kelas merupakan penampilan dari kelas-kelas atau relasi antara kelas-kelas yang ada di dalam suatu sistem.

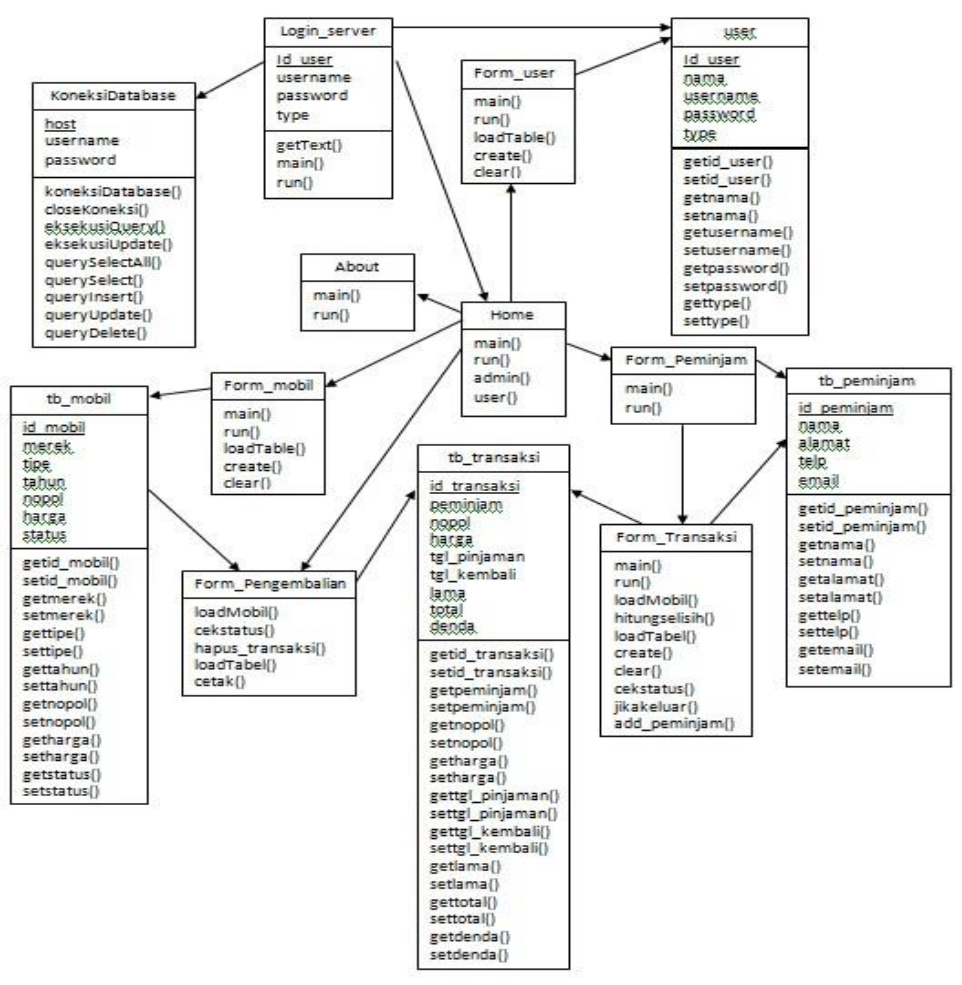

Gambar 3.6 Diagram Kelas Basis Data rental_mobil

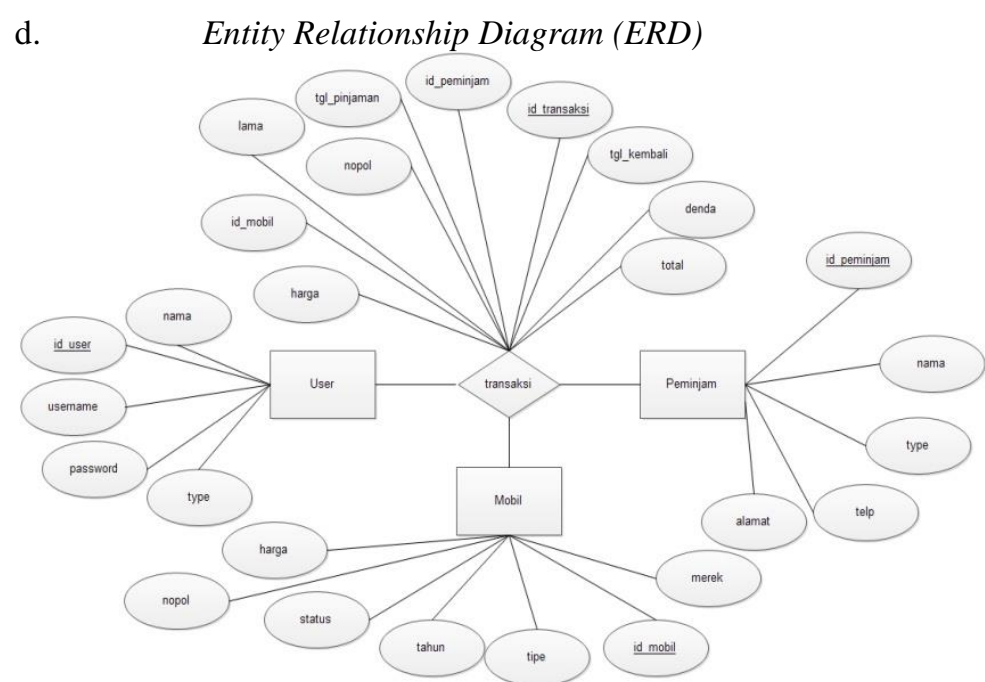

Gambar 3.7 Relationship Entity Diagram transaksi

4. Spesifikasi Basis Data

Spesifikasi basis data memberikan penjelasan secara detil tentang masing-masing basis data.

a. Tabel User

Nama file

Isi

$\begin{array}{ll}: \text { user } \\ \text { : } \\ \text { merupakan } & \text { field yang } \\ \text { berisi } & \text { data-data } \\ \text { pengguna } & \text { sistem } \\ \text { informasi } & \\ : \text { id user } & \end{array}$

Primary Key : id_user

Tabel 3.2 Spesifikasi Field Tabel User

\begin{tabular}{|c|c|c|c|c|c|}
\hline No. & Field & Jenis & Lebar & Desimal & Keterangan \\
\hline 1. & Id_user & integer & 11 & - & Primary Key \\
\hline 2. & nama & varchar & 30 & - & Field \\
\hline 3. & usemame & varchar & 20 & - & Field \\
\hline 4. & password & varchar & 20 & - & Field \\
\hline 5. & type & varchar & 20 & - & Field \\
\hline
\end{tabular}

b. Tabel Mobil

Nama file : tb_mobil

Isi : merupakan field yang

berisi data-data mobil

Primary Key : id_mobil

Tabel 3.2Spesifikasi Field Tabel Mobil

\begin{tabular}{|c|c|c|c|c|c|}
\hline No. & Field & Jenis & Lebar & Desimal & Keterangan \\
\hline 1. & id_mobil & integer & 20 & - & Primary Key \\
\hline 2. & merek & varchar & 20 & - & Field \\
\hline 3. & tipe & varchar & 20 & - & Field \\
\hline 4. & tahun & varchar & 20 & - & Field \\
\hline 5. & nopol & varchar & 10 & - & Field \\
\hline 6. & harga & integer & 20 & - & Field \\
\hline 7. & status & varchar & 20 & - & Field \\
\hline
\end{tabular}


c. Tabel Peminjam

Nama file : tb_peminjam

Isi : merupakan field yang

berisi data-data penyewa mobil

Primary Key : id_peminjam

Tabel 3.3 Spesifikasi FieldTabel Peminjam

\begin{tabular}{|c|c|c|c|c|c|}
\hline No. & Field & Jenis & Lebar & Desimal & Keterangan \\
\hline 1. & id_peminjam & integer & 20 & - & Primary Key \\
\hline 2. & nama & varchar & 20 & - & Field \\
\hline 3. & alamat & varchar & 50 & - & Field \\
\hline 4. & telp & varchar & 20 & - & Field \\
\hline 5. & email & varchar & 20 & - & Field \\
\hline
\end{tabular}

\section{d. Tabel Transaksi}

Nama file : tb_transaksi

Isi : merupakan field yang

berisi data-data transaksi

Primary Key : id_transaksi

Tabel 3.4 Spesifikasi Field Tabel Transaksi

\begin{tabular}{|c|c|c|c|c|c|}
\hline No. & Field & Jenis & Lebar & Desimal & Keterangan \\
\hline 1. & id_transaksi & integer & 20 & - & Primary Key \\
\hline 2. & id_mobil & integer & 20 & - & Field \\
\hline 3. & id_peminjam & varchar & 20 & - & Field \\
\hline 4. & nopol & varchar & 20 & - & Field \\
\hline 5. & harga & varchar & 20 & - & Field \\
\hline 6. & tgl_pinjaman & date & - & - & Field \\
\hline 7. & tgl_kembali & date & 20 & - & Field \\
\hline 8. & lama & varchar & 10 & - & Field \\
\hline 9. & total & varchar & 20 & - & Field \\
\hline 10. & denda & varchar & 20 & - & Field \\
\hline
\end{tabular}

\section{IMPLEMENTASI DAN PENGUJIAN}

A. Spesifikasi Perangkat Lunak yang Digunakan Sistem Informasi Rental Mobil ini dibuat sedemikian rupa dengan antarmuka yang cantik namun sederhana sehingga pengguna merasa dimudahkan saat menggunakan aplikasiini. Aplikasi ini diimplementasi dengan menggunakan :

1. Sistem Operasi : Microsoft Windows 7

2. Web Server : Apache
3. Database
: $\quad$ MySQL; PHPMyAdmin

4. Editor

5. Browser

: Netbeans

: Mozilla Firefox

B. Implementasi Basis Data

Langkah pertama adalah dengan membuat basis data bernama rental_mobil yang mempunyai delapan buah tabel, yaitu: user,tb_mobil, tb_peminjam, dan tb_transaksi. Daftar tabel-tabel tersebut dapat dilihat pada gambar 4.1 berikut ini.

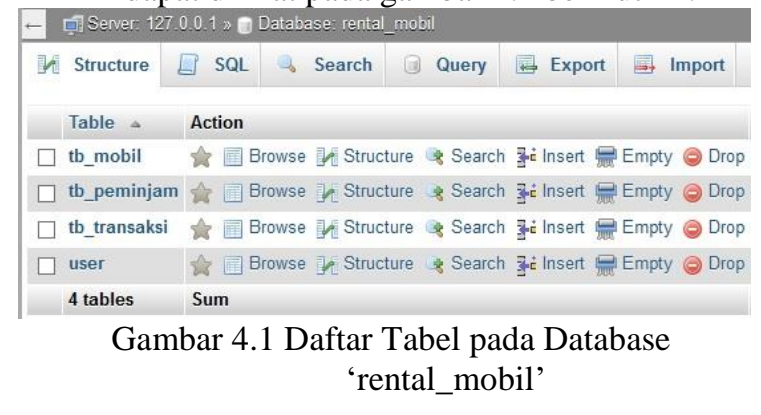

Cara membuat basis data tersebut adalah dengan membuka aplikasi phpMyAdmin melalui browser. Ketikkan http://127.0.0.1/phpmyadmin pada URL box maka browser akan menampilkan halaman dimana pengembang dapat mengkonfigurasi basis data sesuai kebutuhan. Pada menu home di phpmyadmin isikan kolom create new table dengan nama rental_mobil lalu klik tombol create maka akan terbentuk basis data bernama rental_mobil. Setelah basis data terbentuk, langkah berikutnya adalah membuat tabel-tabel.

C. Implementasi Antarmuka Pengguna

Pada bagian ini ditampilkan hasil implementasi dari aplikasi yang telah dikembangkan dengan berdasar pada rancangan sistem (yang telah dibahas sebelumnya pada BAB III). Berikut ini adalah gambar seluruh tampilan layar pada Sistem Informasi Rental Mobil :

a. Halaman Login

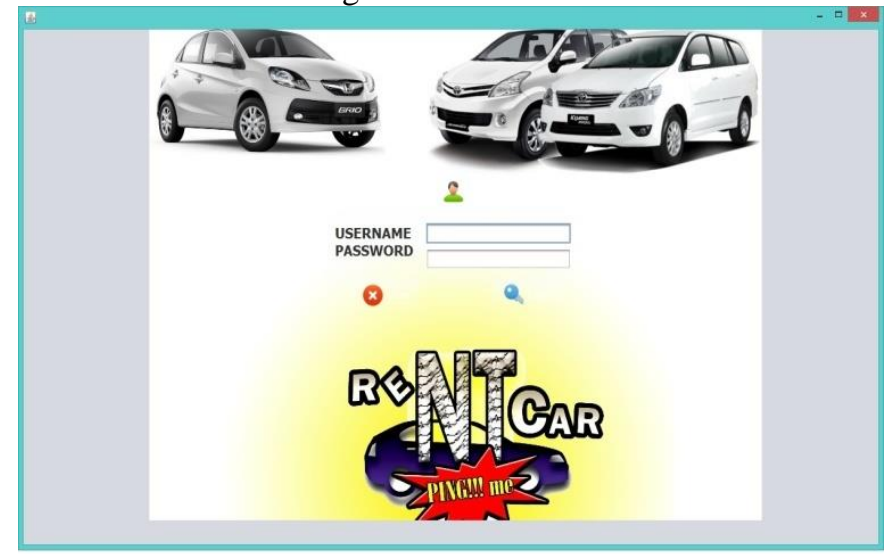

Gambar 4.2 Screenshot Antarmuka Halaman Login Sistem Informasi Rental Mobil 
b. Halaman About

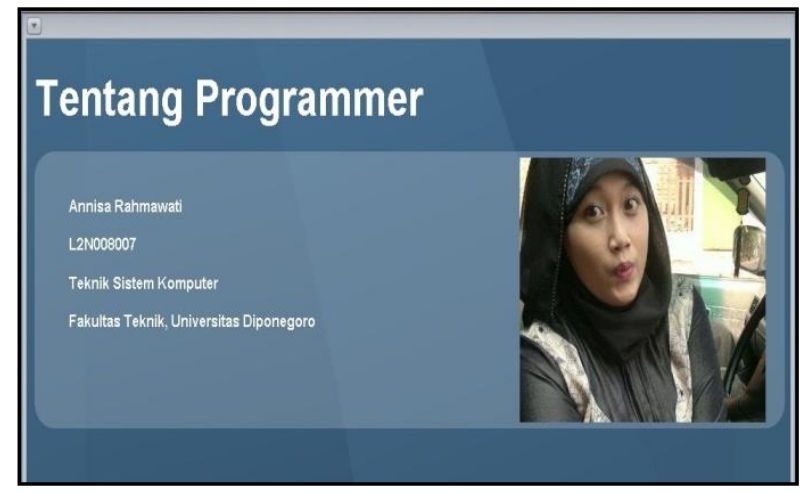

Gambar 4.3 Halaman About

c. Halaman Form Tambah Mobil

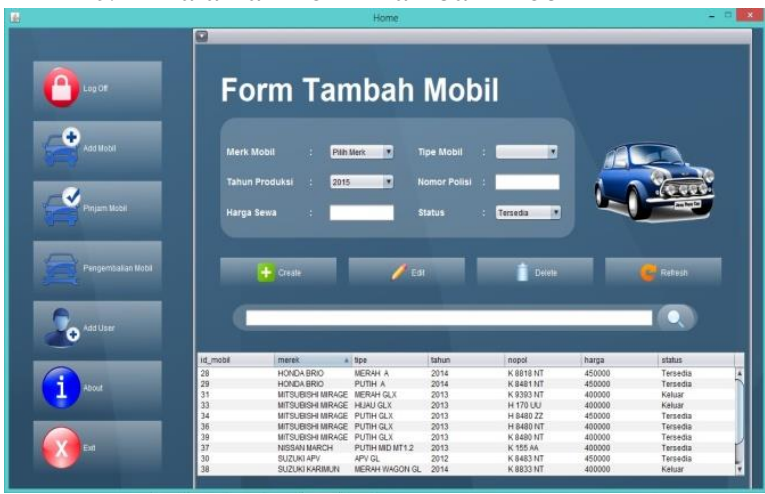

Gambar 4.4 ScreenshotHalaman Form Tambah Mobil

d. Halaman Form Peminjaman Mobil

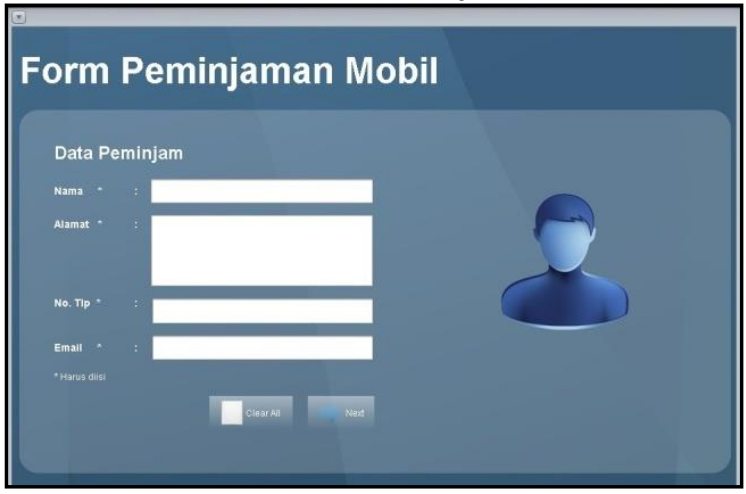

Gambar 4.5 Screenshot Halaman Form Peminjaman Mobil

\section{e. Halaman Form Pengembalian Mobil}

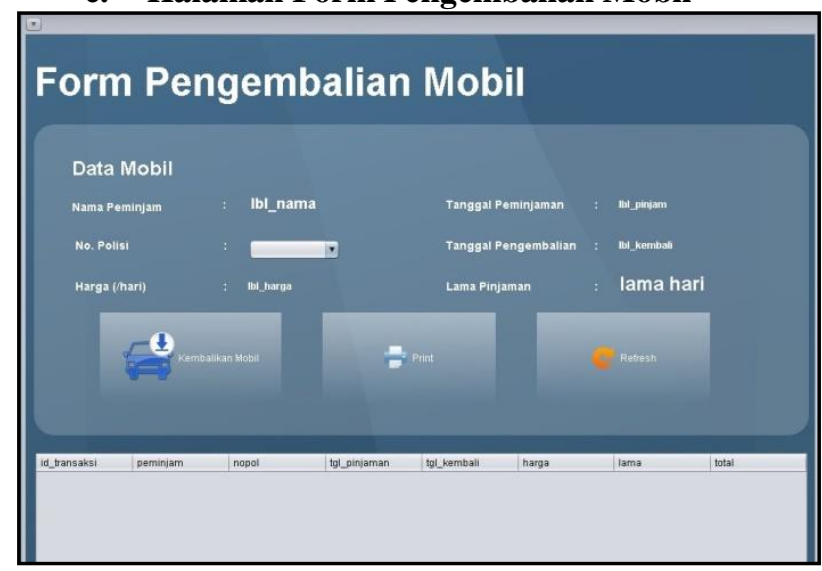

Gambar 4.6 Screenshot Halaman Form Pengembalian Mobil

\section{f. Halaman Form Tambah User}

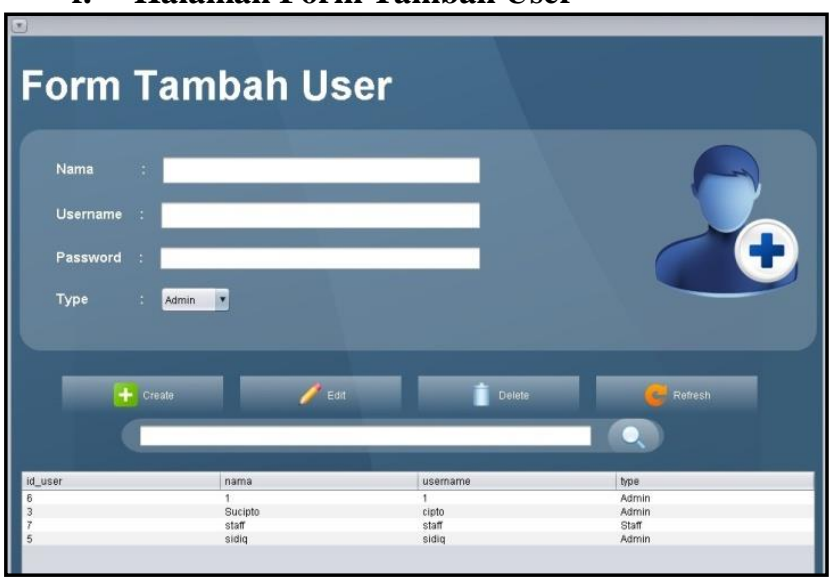

Gambar 4.7 Halaman Form Tambah User

D. Pengujian

Bentuk pengujian ini berupa analisis dan disimpulkan berdasarkan hasil pengujianpengujian yang telah dilakukan sebelumnya.

Tabel 4.1 Hasil Pengujian Kebutuhan Fungsional

\begin{tabular}{|c|l|c|}
\hline No. & Pengujian Fungsional & Keterangan \\
\hline 1. & $\begin{array}{l}\text { Adanya halaman Login } \\
\text { yang berfungsi untuk } \\
\text { membagi hak akses } \\
\text { pengguna sesuai dengan } \\
\text { username dan password } \\
\text { yang diberikan. }\end{array}$ & Ada \\
\hline 2. & $\begin{array}{l}\text { Adanya halaman Add } \\
\text { Mobil agar admin dapat } \\
\text { menambahkan data } \\
\text { mobil baru juga } \\
\text { mengubah dan } \\
\text { menghapus data mobil }\end{array}$ & Ada \\
\hline
\end{tabular}




\begin{tabular}{|c|c|c|}
\hline & lama. & \\
\hline 3. & $\begin{array}{l}\text { Adanya halaman Pinjam } \\
\text { Mobil sebagai fasilitas } \\
\text { untuk memasukkan data } \\
\text { transaksi. }\end{array}$ & Ada \\
\hline 4. & $\begin{array}{l}\text { Adanya halaman } \\
\text { Pengembalian Mobil } \\
\text { sebagai fasilitas untuk } \\
\text { menghapus data } \\
\text { transaksi saat penyewa } \\
\text { telah mengembalikan } \\
\text { mobil yang disewanya. }\end{array}$ & Ada \\
\hline 5. & $\begin{array}{l}\text { Adanya halaman Add } \\
\text { User untuk } \\
\text { menambahkan data } \\
\text { pengguna baru yang } \\
\text { diberi hak akses untuk } \\
\text { masuk ke dalam sistem. }\end{array}$ & Ada \\
\hline 6. & $\begin{array}{l}\text { Adanya halaman About } \\
\text { untuk menampilkan } \\
\text { informasi dari } \\
\text { programmer. }\end{array}$ & Ada \\
\hline 7. & $\begin{array}{l}\text { Adanya fitur untuk } \\
\text { melihat mobil mana saja } \\
\text { yang sedang tersedia } \\
\text { dan mobil mana yang } \\
\text { sedang dipinjam. }\end{array}$ & Ada \\
\hline 8. & $\begin{array}{l}\text { Adanya fitur untuk } \\
\text { keluar dari Sistem } \\
\text { Informasi Rental Mobil } \\
\text { dengan menekan tombol } \\
\text { Exit. }\end{array}$ & Ada \\
\hline
\end{tabular}

Tabel 4.2 Hasil Pengujian Kebutuhan NonFungsional

\begin{tabular}{|c|l|c|}
\hline No. & \multicolumn{1}{|c|}{$\begin{array}{c}\text { Pengujian Non- } \\
\text { Fungsional }\end{array}$} & Keterangan \\
\hline 1. & $\begin{array}{l}\text { Sistem harus mampu } \\
\text { melakukan verifikasi } \\
\text { pengguna berdasarkan } \\
\text { username dan password. }\end{array}$ & OK \\
\hline 2. & $\begin{array}{l}\text { Hanya pengguna yang } \\
\text { sudah terdaftar di basis } \\
\text { data yang dapat sukses } \\
\text { login/masuk ke Sistem } \\
\text { Informasi Rental Mobil. }\end{array}$ & OK \\
\hline 3. & $\begin{array}{l}\text { Admin dapat mengakses } \\
\text { semua halaman. }\end{array}$ & OK \\
\hline 4. & $\begin{array}{l}\text { Staff hanya dapat } \\
\text { mengakses halaman } \\
\text { tertentu saja dan hanya } \\
\text { dapat memasukkan data } \\
\text { transaksi baru serta } \\
\text { mengakses halaman } \\
\text { pengembalian mobil. }\end{array}$ \\
\hline
\end{tabular}

\begin{tabular}{|c|l|c|}
\hline 5. & $\begin{array}{l}\text { Menggunakan } \\
\text { mekanisme enkripsi } \\
\text { password MD5. }\end{array}$ & OK \\
\hline
\end{tabular}

Pengujian unit pun perlu dilakukan untuk memastikan bahwa setiap unit pada sistem bekerja dengan baik. Pengujian juga dilakukan pada integrasinya dengan unit lain untuk menguji kinerja dan hubungan antarunit berjalan sebagaimana mestinya. Tabel berikut ini menampilkan hasil pengujian unit dan integrasi.

Tabel 4.3 Hasil Pengujian Unit dan Integrasi

\begin{tabular}{|l|l|l|l|}
\hline No. & Pengujian & Proses & Pesan Berhasil dan Kesalahan \\
\hline 1. & Login user & $\sqrt{ }$ & $\sqrt{ }$ \\
\hline 2. & Menu Admin & & \\
\hline & Form Tambah Mobil & $\sqrt{ }$ & \\
\hline & Form Peminjaman Mobil & $\sqrt{ }$ & \\
\hline & Form Pengembalian Mobil & $\sqrt{ }$ & \\
\hline & Form Tambah User & $\sqrt{ }$ & \\
\hline 3. & Menu Guru & & \\
\hline & Form Peminjaman Mobil & $\sqrt{ }$ & \\
\hline & Form Pengembalian Mobil & $\sqrt{ }$ & \\
\hline & Ubah Password & $\sqrt{ }$ & \\
\hline 4. & About & $\sqrt{ }$ & \\
\hline 5. & Exit & $\sqrt{ }$ & $\sqrt{ }$ \\
\hline
\end{tabular}

E. Analisis Hasil Pengujian

Setelah melakukan tindak pengujian terhadap semua unit (menu pilihan) yang terdapat pada Sistem Informasi Rental Mobil ini, dapat disimpulkan bahwa hasil keluaran yang ditunjukkan selama proses pengujian sesuai dengan rancangan perangkat lunak sistem informasi ini. Maka dapat dikatakan bahwa Sistem Informasi Rental Mobil ini telah dapat berfungsi dengan baik dan benar.

\section{PENUTUP}

A. Kesimpulan

Dari pembahasan pada bab-bab sebelum ini, kesimpulan yang dapat diambil adalah sebagai berikut:

1. Menurut hasil pengujian yang telah dilakukan, diketahui bahwa hasil keluaran yang ditunjukkan selama proses pengujian sesuai dengan rancangan sistem informasi rental mobil.

2. Sistem Informasi Rental Mobil ini telah berhasil dikembangkan dan dapat berfungsi dengan baik dan benar.

3. Sistem yang dibangun merupakan aplikasi berbasis desktop yang dapat dijalankan langsung pada komputer dengan sistem operasi windows 7. 
4. Sistem Informasi Rental Mobil NT Rent Car dikembangkan dengan menggunakan basis data MySQL sebagai media penyimpanan datanya.

B. Saran

Berikut ini adalah saran yang penulis harap akan berguna dalam mendukung kelancaran berjalannya sistem yang diusulkan :

1. Sistem dipelihara dengan baik supaya mampu terus berjalan sesuai dengan yang diharapkan. Pemeliharaan dapat dilakukan dengan cara mengecek kondisi perangkat keras dan perangkat lunak sistem secara teratur.

2. Sistem Informasi rental mobil NT Rent Car ini dapat dikembangkan lebih lanjut dengan menambahkan fitur untuk melihat kinerja dari karyawan sehingga dapat menjadi evaluasi dari kinerja karyawan tersebut.

3. Karyawan NT Rent Car yang ditugaskan sebagai admin ataupun staf pengguna sistem informasi ini diharapkan untuk meningkatkan ketelitian pada saat memasukkan data dan penghapusan atau proses pengembalian supaya tingkat kesalahan hasil keluaran dapat diminimalisir sehingga hasil yang didapat sesuai dengan yang kenyataan di lapangan.

\section{DAFTAR PUSTAKA}

1. Al Fatta, Hanif. 2007. Analisis dan Perancangan Sistem Informasi untuk Keunggulan Bersaing Perusahaan dan Organisasi Modern. Yogyakarta: Penerbit ANDI.

2. Asmarul, Amri, Geografi dan Sistem Informasi Geografis, Departemen Geografi Universitas Indonesia, Depok, 2000

3. Gaol, Chr., Jimmy L., Sistem Informasi Manajemen: Pemahaman dan Aplikasi, Grasindo, Jakarta,2008.

4. Hariyanto, Bambang. 2014. Esensi-Esensi Bahasa Pemograman JAVA (Revisi Keempat). Bandung: Penerbit Informatika.

5. Kadir, Abdul. 2014. Buku Pertama Belajar Pemograman Java untuk Pemula. Yogyakarta: Mediakom.

6. Kurniawan, Agus. 2014. Pemograman Java Tingkat Lanjut. Berlin: Penerbit ANDI.

7. Nugroho, Adi. 2002. Analisis Dan Perancangan Sistem Informasi Dengan Metodologi Berorientasi Objek. Bandung: Graha Ilmu.
8. Pohan, Husni Iskandar., dkk, 1997. Pengantar Perancangan Sistem, Jakarta : Erlangga

9. Proboyekti, Umi. Software Process Model I [pdf].

(http://www.lecturer.ukdw.ac.id/othie/softwarep rocess.pdf, diakses 3 April 2012).

10. Simarmata, Janner, Rekayasa Perangkat Lunak, Andi Publisher, Jakarta,2007.

11. Sutabri, Tata. 2003. Analisa Sistem Informasi. Yogyakarta: Andi.

12. Whitten, Jeffrey L.,dkk., Metode Desain dan Analisis Sistem Edisi 6 Bahasa Indonesia, CV. Andi Offset., Yogyakarta, 2004.

13. Yakub, 2012, Pengantar Sistem Informasi, Yogyakarta: Graha Ilmu 